\title{
TEACHING THE SPECIFIC FEATURES OF VOCABULARY IN NEWSPAPER HEADLINES
}

\author{
Svetlana Iljina \\ Rezekne Academy of Technologies, Latvia
}

\begin{abstract}
The present research deals with the variety of lexical items used in newspaper headlines in British press. The report discusses teaching strategies how to develop readers' vocabulary competence and its influence on the overall comprehension of the meaning implied in the headline. The study touches upon the strategy of direct explanation of new vocabulary, morphemic analysis of words, and stylistic analysis of the phraseological units used in newspaper headlines. The research emphasizes the role of emotively coloured vocabulary in the formation of attractive headlines.
\end{abstract}

Keywords: components, compounds, figurative meanings, morphological transformations, readership, word-formation.

\section{Introduction}

Teaching vocabulary in the EFL classroom is one of the most important aspects of language study. Vocabulary builds up the bulk of any language. Vocabulary plays a major role in the development of communicative skills, reading comprehension skills, literary discourse analysis, and reinforcing overall academic competence. The development of vocabulary competence is vital for university students, especially for students of philology and linguistics, as they encounter with a wide range of discourse including various genres, styles, and themes. It is of utmost importance to be able to decode the meanings of unfamiliar vocabulary items as well as new coinages, neologisms, and phrases with figurative meanings. Newspapers offer never-ending resources for developing linguistic competence. Modern EFL methodology abounds in appropriate techniques for sufficient vocabulary instruction in the language classrooms. Students majoring in the language study will always find the language of newspapers the most sensitive to the latest tendencies both in their mother tongue and in the foreign language.

The present research is focused on the role of headlines in the improvement of literacy skills of the tertiary level students. The aim of the research is to explore the strategies that will facilitate the learners' vocabulary competence, observe the word formation processes in creating new vocabulary items, meanings and additional connotations in situational contexts. The research 
methodology is based on the principles of discourse analysis and componential analysis of particular lexical items.

\section{The Research}

The headline is 'a unique type of text' that has several functions (Reah 2002 , 13). The primary function of the headline is to inform the reader of the main idea of the article. To achieve this effectively, the author of the headline, or the text producer, has to be very skilful when selecting the appropriate words or expressions. Headline writers have established a specific text type that is found only in newspapers. The reason for that is the strategy of attracting more readers to a particular article and the newspaper itself. Therefore, the vocabulary that the headline writers use must be short, attention-getting, even memorable and striking (Reah, 2002).

According to Alain de Botton (2014: 11), the news has its own 'mechanics' how to present the information to the readership; however, the propositional content of the headline is not always observed. The power of the headline is also laden in the ability to transfer the ideology that is 'creating a new planet in our minds' (Botton 2014, 11). The research discloses the power of words and lexical items in the formation of attractive and 'loaded' headlines with the help of morphological strategies and the use of stylistically marked vocabulary.

\section{Morphemic Analysis Strategy}

The English language is very flexible in terms of creating new words and lexical units. Word building principles provide a fruitful background for creating words to lexicalize new concepts or contracted means of expressing long phrases or even sentences. Word formation contributes freshness and originality to the headlines, which makes the headlines attractive to the readership. A wide range of possible morphological transformations trigger the headline writers' creativity and imagination. Moreover, due to the morphological transformations, the headline may carry an enormous amount of information to the reader. To avoid long descriptive and explanatory sentences or expressions, the authors may choose the most appropriate type of word building. Let us look at the most common ways of word building found in newspaper headlines in British quality press. The following headlines have been selected to illustrate the latest tendencies in word building.

1) 'New grammar schools will kick-start social mobility' (9 Dec 2014, The Telegraph)

2) A-Level results: a stress-free survival guide (14 Aug 2014, The Independent)

3) All private schools 'to be given Ofsted-style inspections' (24 Jun 2014, The Independent) 
4) Exclusive: Tories under fire for links to pro-Russia lobbyists (03 July 2014, The Independent)

5) Ministers urged not to rush through heavy-handed anti-terror legislation (25 Aug 2014, The Independent)

6) More university students means more drop-outs, claims senior vicechancellor (9 Nov 2014, The Independent)

7) Road-building blitz: David Cameron targets key marginal votes with $£ 15 \mathrm{bn}$ investment scheme (10 Nov 2014, The Independent)

8) Home Office quietly ditches Swedish firm contracted to process asylumseekers (14 Nov 2014, The Independent)

9) Andy Burnham challenges Nigel Farage over NHS 'cover-up' in open letter (14 Nov 2014, The Independent)

10) Anti-terror law 'would stop British jihadists coming home for two years', says David Cameron (13 Nov 2014, The Independent)

11) The 'zero-zero' economy: Labour announces new plans to crack down on large-scale tax avoidance (13 Nov 2014, The Independent)

12) Rochester and Strood ,: Ukip predicts 15-point lead as Tories brace for defeat (17 Nov 2014, The Independent)

13) David Cameron may seek only short-term EU migration limits, says Major (17 Nov 2014, The Independent)

14) Ed Miliband leadership turmoil was 'Labour's four-year itch', MP says (16 Nov 2014, The Independent)

15) Andy McSmith's Diary: I'm an Attention-Seeking Politician...Get Me in There (17 Nov 2014, The Independent)

16) Migrants storm UK-bound lorries at Calais (20 Oct 2014, The Telegraph)

On the basis of empirical examination of a corpus of newspaper headlines the most common type of word formation is a hyphened compound. The component parts, such as nouns, verbs, adjective, adverbs, and gerunds are most frequently hyphened to combine two or more propositional contexts and to signal the individual meaning of each component. Some of the compounds have already become a part of common colloquial (e.g. drop-outs, large-scale, stressfree) and common literary vocabulary (e.g. vice-chancellor, anti-terror, asylumseekers, short-term, by-election).

Direct Explanation Strategy

The compounds that are less common are mostly based on the spontaneity and originality levels. This type of compounds requires the readers' background knowledge or the language instructor's additional explanation of the facts or the cultural references to decode the implied meaning of the words and word combinations. For instance, Ofsted-style inspections may confuse the less informed reader what type of inspections these are. In fact, Ofsted is a government body that inspects and assesses the educational standards in England and Wales on a confidential basis. Similarly, the compound zero-zero 
economy is used in the sphere of economics, which is equivalent to steady-state economy that has stable population and stable consumption. Being neutral, at first sight, the compound attention-seeking provokes an irony to some extent. The phrase sounds similar to asylum-seeking referring to the growing number of refugees in European countries. Another group of compounds are made by affixation that carries a particular meaning, like pro-Russia, anti-terror, UKbound, by-election. The authors of the headlines presuppose that the readers are knowledgeable people with good literacy skills. The use of meaningful affixes saves the space that is rather limited. For instance, pro- means 'in favour of', anti- means 'against', -bound means 'restricted, confined, within the borders of', by- means a special election to fill a vacant seat in the lower chamber of the Parliament.

The vocabulary units that have become a part of commonly used discourse in formal contexts and in political rhetoric are easily recognised by the readership. Martin (1988: 9) emphasises that language is distinguished by two properties that are its infinity and the capacity for novelty. A great number of lexical units appear due to morphological transformations, blending, clipping, and other word construction techniques. These techniques facilitate the readers' ability to understand words and word combinations they have never seen or used before. The following examples of headlines demonstrate the usage of other types of word building.

17) Nicky Morgan: pupils 'held back' by overemphasis on arts (10 Nov 2014, The Telegraph)

18) Oxbridge degrees add $£ 7,600$ to graduate starting salaries (18 Dec 2014, The Telegraph)

19) Homework 'damages' primary age pupils (5 Oct 2014, The Independent)

20) Commonwealth Games 2014: Alex Salmond photobombed by spectator with English flag ( 3 Aug 2014, The Independent)

21) Ed Miliband fights for his political life amid rumours of Labour backbench coup_(6 Nov 2014, The Independent)

22) Eurosceptic and male? Join the Peter Party! (16 Nov 2014, The Independent)

The words that consist of two words with their own individual meanings have entered the language as common literary vocabulary. The complete integration into the lexicon facilitates entire comprehension of the notion that they represent. The compounds like 'homework' (the work done at home), 'backbench' (the seats at the back of a hall), 'Eurosceptic' (someone who is doubtful of the idea of united Europe), 'overemphasis' (too much emphasis), 'photobombed' (appearing unexpectedly in a photograph) do not require additional background knowledge or situational context to get the proper 
meaning. The most well-known blend in the sphere of education terminology is Oxbridge meaning the most popular universities in Oxford and Cambridge.

Stylistic Analysis Strategy

Apart from word formation techniques that ensure a very effective and lexically productive means of creating new words and expressions in newspaper language, there is another group of lexical items that make the language of headlines emotionally and stylistically bright. These are the words and phrases of neutral and common literary vocabulary that convey figurative meanings. Learners' linguistic competence and prior knowledge of conventional dictionary meanings of words will facilitate comprehension of the words' transferred meanings. Readers are supposed to grasp the intended meaning of expressions from the written context. Text producers frequently exploit figurative language to avoid direct and sometimes blunt messages. Phraseological units that are used in headlines metaphorically smoothen the actual state of matters. The following examples of newspaper headlines illustrate a wide range of phraseological units that may expand the learners' vocabulary in the process of advanced language study.

23) Foreign criminals scandal: Politicians 'have blood on their hands', says grieving father (22 Oct 2014, The Telegraph)

24) Duke of Edinburgh was 'put in his place' by Cecil Beaton during coronation (31 Oct 2014, The Telegraph)

25) Britain will become 'safe haven for criminals' without European Arrest Warrant (30 Oct 2014, The Telegraph)

26) Top Labour figures rally around Ed Miliband, warning revolt 'muttering' could cost party next election (7 Nov 2014, The Independent)

27) George Osborne accused of fuelling 'ignorance' over welfare claims (4 Nov 2014, The Independent)

28) Alex Salmond departs as Scotland's First Minister - but this ruthless political operator is not going to fade away (13 Nov 2014, The Independent)

29) David Cameron 'must tone down anti-EU rhetoric', insists Sir John Major (13 Nov 2014, The Independent)

30) Alex Salmond steps down as Scotland's First Minister - but he won't be gone for long (13 Nov 2014, The Independent)

31) MPs warn Government not to allow 'dilution' of banking reforms (17 Nov 2014, The Independent)

32) Rochester by-election: The gloves are off as the Tories and Ukip do battle by the Medway (16 Nov 2014, The Independent)

The denotational meanings of the phraseological units found in the headlines trigger the learners' imagination to facilitate the entire understanding of the implied meaning of the word combinations. The metaphorical meanings have been derived from the conventional meanings of the words and phrases. 
The meanings can be easily understood from the context. The table demonstrates the origin of the phraseological units that were found in the headlines.

Table 1 The origin of figurative meanings

\begin{tabular}{|c|c|c|}
\hline Phraseological unit & Conventional meaning & Metaphorical meaning \\
\hline have blood on one's hands & $\begin{array}{l}\text { Have blood on one's hands } \\
\text { after murder }\end{array}$ & $\begin{array}{l}\text { Be accused of indecent } \\
\text { behaviour }\end{array}$ \\
\hline put in one's place & Show the right place & Told to observe certain rules \\
\hline safe haven & Safe place & Peaceful, remote place \\
\hline rally around & Move around & $\begin{array}{l}\text { Trying to persuade or warn } \\
\text { about sth }\end{array}$ \\
\hline to fade away & Lose vitality & Lose vividness and authority \\
\hline fuelling 'ignorance' & Emphasized ignorance & Intentional ignorance \\
\hline tone down & Make the sound quieter & Speak in more mild language \\
\hline step down & Go downstairs & Quit the present position \\
\hline won't be gone & Will not go away & $\begin{array}{l}\text { Will temporarily leave the } \\
\text { position }\end{array}$ \\
\hline dilution & $\begin{array}{ll}\text { Making substance less } \\
\text { concentrated }\end{array}$ & Damage \\
\hline The gloves are off & $\begin{array}{l}\text { To argue or compete in a } \\
\text { more unpleasant way }\end{array}$ & $\begin{array}{l}\text { Ready to defend one's } \\
\text { opinion aggressively }\end{array}$ \\
\hline do battle & To fight, struggle & To argue, to quarrel \\
\hline
\end{tabular}

The use of emotively coloured vocabulary brings vividness to the discourse. The text producers transfer the atmosphere of the events, actions, and characterize interpersonal relationships. The phraseological units are mostly encountered in informal texts, which establish closeness to the readership and availability of the comprehension of the implied messages. Figurative meanings transfer different emotions and attitudes, such as criticism, warning, exaggeration, disapproval, doubt, accusation, assurance, and irony.

In conclusion, it may be stated that the language of newspapers and newspaper headlines add variety and diversity into the language study process. Linguistic and stylistic devices provide learners with the access to many 'sets of semantic settings' (Fowler 1991, 31). Referring to the lexical units known in habitual usage makes the entire comprehension of the implied message easy and approachable. The English language is extremely diverse in linguistic techniques how to explain complicated things and notions. Language teachers and instructors should apply diverse vocabulary learning strategies to deepen learners' knowledge of word meanings and motivate their desire to acquire new vocabulary. New concepts are explained with the help of invented words, neologisms, borrowings, culture-specific vocabulary. In other words, the 
expansion of the language vocabulary is entirely influenced by the latest developments and innovations in the human society.

\section{References}

Bagnall, N.( 1993). Newspaper Language. Oxford: Focal Press.

Botton, A. (2014). The News. A User's Manual. England: Penguin Books.

Fowler, R. (1991). Language in the News. Great Britain: Routledge.

Longman Dictionary of Contemporary English (2005). England: Pearson Education Limited. Martin, R. M. (1988). The Meaning of the Language. USA: The MIT press.

Reah, D. (2002). The Language of Newspapers: 2nd ed. Great Britain: Routledge. 